\title{
Identifikasi Kadar Amoniak sebagai Indikator Bau Toilet Menggunakan Perangkat MAS TUQUL
}

\author{
Salsabila Nurulfarah Mahmudah ${ }^{1 *}$, Heni Hanifah ${ }^{1}$, Wahyu Titis Satria Utama ${ }^{2}$, \\ Ismi Kamelia Najib Putri ${ }^{1}$, Rahmat Kurniawan ${ }^{3}$, Husni Thamrin ${ }^{1}$ \\ ${ }^{1}$ Program Studi Informatika \\ Univeritas Muhammadiyah Surakarta \\ ${ }^{2}$ Program Studi Teknik Elektro \\ Universitas Muhammadiyah Surakarta \\ ${ }^{3}$ Program Studi Teknik Kimia \\ Universitas Muhammadiyah Surakarta \\ *1200160132@student.ums.ac.id
}

\begin{abstract}
Abstrak
Toilet merupakan tempat untuk melakukan ekskresi. Kegiatan ekskresi ini terdapat 2 wujud zat, yaitu berupa zat cair atau urin dan keringat, dan zat padat berupa feses. Urin manusia menyuplai setidaknya $1 \%$ terhadap kuantitas air limbah domestik dengan $80 \%$ nitrogen dan 50\% fosfat. Kebutuhan untuk melakukan ekskresi menjadikan pentingnya toilet di setiap tempat, baik di rumah maupun di tempat umum. Kebutuhan itu perlu diimbangi dengan tersedianya toilet layak pakai, yang memperhatikan kebersihan, kenyamanan dan kesehatan bagi pengguna. Kenyamanan toilet, bau toilet umum, dapat diidentifikasi dengan mengetahui kadar amoniak. Hubungan antara kadar amoniak dengan bau di toilet dapat dinyatakan dengan persamaan $\mathrm{Y}=$ $1.8045+0.5836 \mathrm{X}$. Y merupakan kategori bau, sedangkan X merupakan kadar amoniak (ppm). Kadar amoniak menyumbang $67 \%$ dari keseluruhan bau yang ada di toilet. Kadar amoniak yang telah disebutkan dalam Peraturan Kesehatan, yakni sebesar 2 ppm. Nilai tersebut termasuk kategori bau biasa. Pada pengukuran berdasarkan bau amoniak ini, Mas Tuqul dapat membacanya dengan benar. Mas Tuqul dapat membaca secara stabil selama 15 menit. Dari hasil pembacaan tersebut, dapat dilihat dengan mudah kadar bau yang ada di dalam toilet. Diharapkan dengan adanya Mas Tuqul ini dapat mempermudah untuk mengetahui keadaan udara yang ada di toilet.
\end{abstract}

Kata Kunci: toilet, amoniak, monitoring, Mas Tuqul.

\section{Pendahuluan}

Toilet merupakan tempat untuk melakukan aktivitas ekskresi (mengeluarkan zat sisa metabolisme). Setiap hari, rata-rata orang melakukan aktivitas buang air besar satu kali dan buang air kecil sebanyak 6-7 kali [1] dengan rata-rata volume urin yang dikeluarkan sebanyak 400-2000 mililiter [2] [3]. Ekskresi yang dilakukan oleh manusia mempunyai dua wujud zat, yaitu berupa zat cair atau urin dan keringat, serta zat padat berupa feses. Urin manusia menyuplai setidaknya $1 \%$ terhadap kuantitas air limbah domestik dengan $80 \%$ nitrogen dan $50 \%$ fosfat [4]. Kebutuhan untuk melakukan ekskresi menjadikan pentingnya toilet di setiap tempat, baik di rumah maupun di tempat umum. Kebutuhan itu perlu diimbangi dengan tersedianya toilet layak pakai, yang memperhatikan kebersihan, kenyamanan, dan kesehatan bagi pengguna.

Menurut Peraturan Menteri Pekerjaan Umum Nomor 24 tahun 2008 tentang Pedoman Pemeliharaan dan Perawatan Bangunan Gedung (lihat tabel pada
Gambar 1), suatu toilet disebut layak jika toilet bersih dan ruangannya tidak berbau amis, pesing, ataupun anyir [5]. Peraturan Menteri Kesehatan Republik Indonesia Nomor 8 Tahun 2014 mengatur tentang pelayanan kesehatan SPA (Sehat Pakai Air). Peraturan itu menyatakan bahwa toilet dikategorikan nyaman jika toilet tersebut mempunyai suhu berkisar antara $22-25$ derajat celcius $\left({ }^{\circ} \mathrm{C}\right)$ dan kelembaban berkisar antara 40-70\% [6].

Namun, banyak toilet di Indonesia yang jauh dari kata layak. Banyak masyarakat baik WNI (Warga Negara Indonesia) ataupun WNA (Warga Negara Asing) yang ada di Indonesia, mengeluhkan kuantitas dan kualitas toilet umum yang ada [7]. Menurut World Economic Forum, kualitas toilet di Indonesia berada pada peringkat 34 dari 144 negara yang diamati [8]. Dengan demikian, kualitas toilet di Indonesia masih relatif rendah. Senada dengan itu, Badan Pusat Statistik menunjukan bahwa akses sanitasi yang layak di Indonesia masih sebesar 55.6\% [9] dan salah satu unsur sanitasi itu adalah toilet. 


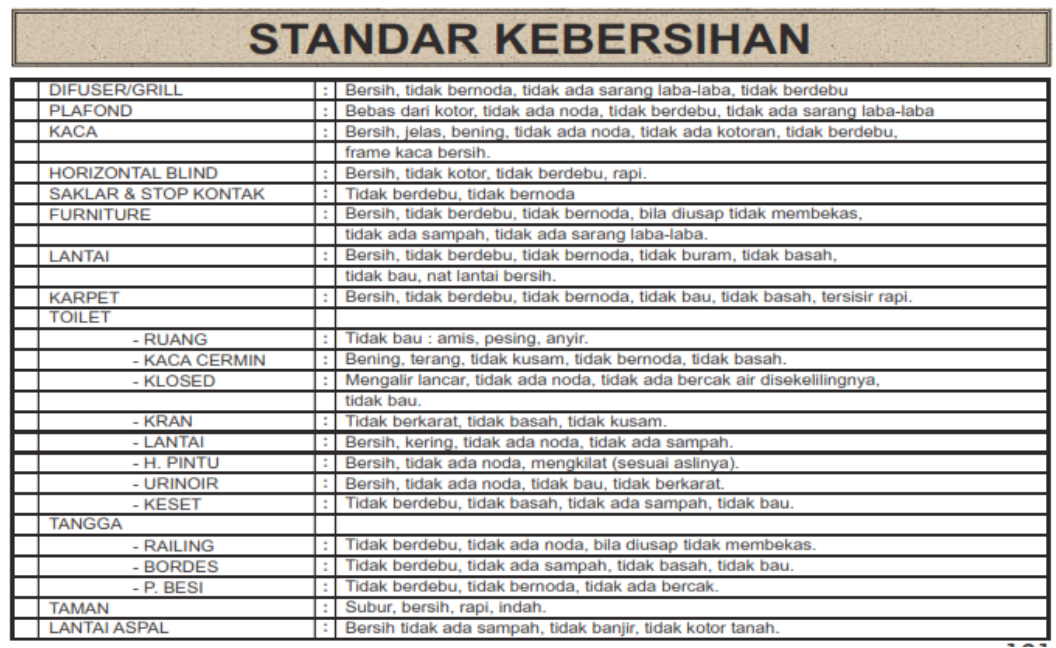

Gambar 1. Cuplikan tabel tentang Standar Kebersihan versi Departemen Pekerjaan Umum [5]

\begin{abstract}
Rendahnya kualitas toilet menimbulkan ketidaknyamanan dan menjadi sumber bakteri yang berbahaya bagi kesehatan. "Toilet tidak higienis merupakan tempat bersarangnya berbagai jenis kuman yang berkembang biak dan berpotensi menjadi sumber penyakit membahayakan," kata dr Rouli Nababan SpA [10]. Setiap 20 menit kuman berkembang biak dan dalam jangka 24 jam 1 sel dapat menjadi 8 juta sel. Berbagai penyakit dapat ditimbulkan, seperti diare, hepatitis A, cacingan, ISPA, tifus, disentri, bahkan infeksi saluran kencing. Belum lagi dengan masalah sanitasi yang mungkin menyebarkan scabies, lice, dan cacing penyebab kaki gajah.

Tulisan ini membahas pengembangan perangkat yang diberi nama MAS TUQUL (Monitoring Ammonia System To Upgrade Quality) yang dapat memantau kandungan amoniak dalam toilet, dengan hipotesis amoniak merupakan material yang signifikan untuk mengindikasikan kualitas toilet. Pemantauan parameter dimaksudkan untuk menjadi bagian dari sistem pemeliharaan kebersihan toilet sehingga diharapkan dapat membantu meningkatkan kualitas toilet khususnya toilet publik. Selanjutnya tulisan ini menguraikan metode pengembangan perangkat, hasil pengembangan perangkat, pengujian di lapangan, dan pembahasan hasil pengujian. Pada pembahasan hasil pengujian, kami menganalisis data-data tersebut, menggunakan metode regresi linier sederhana dan siginifikan atau tidaknya amoniak ditunjukkan dengan nilai koefisien determinasi.
\end{abstract}

\section{Metode}

Perangkat keras yang digunakan dalam proses pengembangan sistem adalah Sensor TGS2602, Power Supply Mini MB102, Adaptor 12V, Kabel RJ45, Acrylic, Ethernet shield, dan Arduino UNO. Perangkat lunak yang digunakan untuk pembangunan alat terdiri atas komputer dengan sistem operasi Windows/Linux, kompailer bahasa $\mathrm{C}$ dan Arduino IDE.

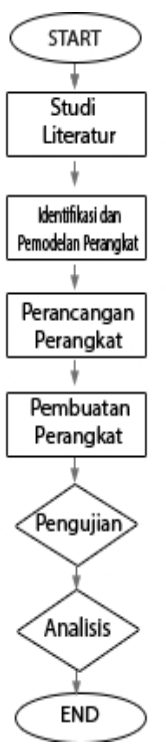

Gambar 2. Diagram alir pelaksanaan

Pengembangan alat melalui enam tahapan sebagaimana ditunjukkan Gambar 2. Masing-masing tahapan dijelaskan sebagai berikut:

a. Studi Literatur Kegiatan ini dilakukan dengan mencari penunjang dari jurnal ilmiah atau makalah. Bahanbahan yang dicari meliputi dua langkah berikut:

a) Metode pembacaan kadar amoniak pada sensor Metode penghitungan kadar amoniak pada sensor merupakan hal dasar penting yang digunakan pada alat ini. Menemukan rumus yang sesuai dengan melakukan penafsiran grafik yang terdapat pada data sheet sensor TGS2602.

b) Batas ambang untuk kadar amoniak bagi manusia Batas ambang suatu zat kimia mempunyai kadarkadar yang berbeda. Untuk amoniak dapat ditemukan di dalam peraturan menteri kesehatan no. 8 tahun 2014 [6]. 


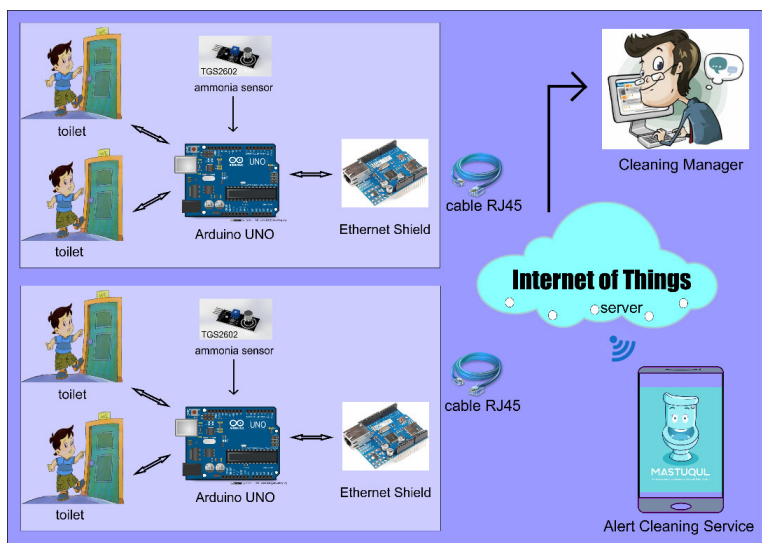

Gambar 3. Skema penerapan/peletakan alat

c) Identifikasi dan Pemodelan Perangkat

Alat ini disusun menggunakan 2 jenis benda utama, yakni 1 jenis sensor dan sebuah mikrokontroler. Sensor tersebut adalah sensor TGS2602. Terdapat banyak sensor yang bisa digunakan untuk mengukur kadar amoniak, namun sensor yang memiliki rentang yang sesuai dengan kebutuhan penelitian kami adalah sensor TGS2602, yakni rentang di antara 0-20 ppm. Untuk sistem yang digunakan, kami menggunakan data yang berasal dari sensor yang berupa sinyal digital. Data tersebut dikirim melalui Ethernet shield, diolah terlebih dulu di servernya dan hasilnya akan ditampilkan pada web yang sudah ada. Skema konfigurasi alat diperlihatkan pada Gambar 3.

d) TGS2602

TGS2602 merupakan sebuah sensor yang bisa digunakan untuk mendeteksi beberapa macam gas kimia. Di antaranya adalah hidrogen sulfida, amoniak, etanol, toluen, air, dan hidrogen. Rentang kepekaan terhadap bau secara keseluruhan cukup besar, yakni mulai dari 0.1 hingga 100 ppm.

e) Arduino UNO

ArduinoUNOmerupakansebuahmikrokontroler berbasis ATmega328. Mempunyai 14 pin digital input/output, 6 input analog, resonator keramik $16 \mathrm{MHz}$, koneksi USB, jack listrik, header ICSP, dan tombol reset. Arduino di sini berguna untuk mengubah sinyal analog menjadi sinyal digital dan mengirim data ke server yang telah diterima oleh sensor.

f) Server

Server merupakan sebuah tempat yang berfungsi untuk menyimpan data yang telah dikirimkan oleh sensor.

g) Toilet

Toilet adalah sebuah tempat yang digunakan untuk mengeluarkan zat-zat sisa hasil pencernaan. Dari zat-zat yang telah dikeluarkan, didapat data berupa angka-angka yang menunjukkan tingkat kebauannya berdasar kadar amoniak.

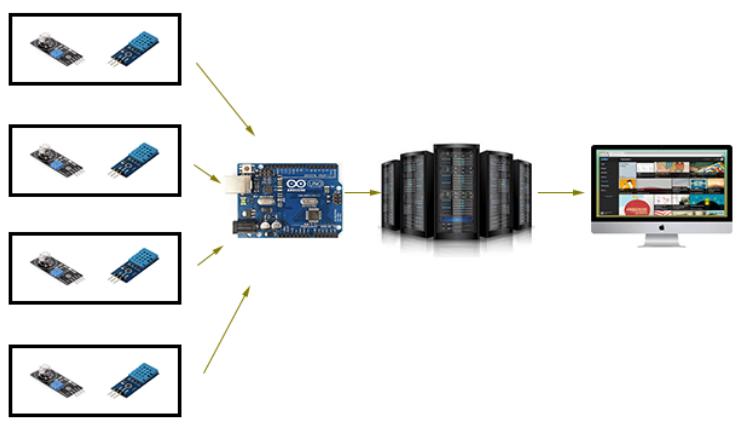

Gambar 4. Alur pengiriman data

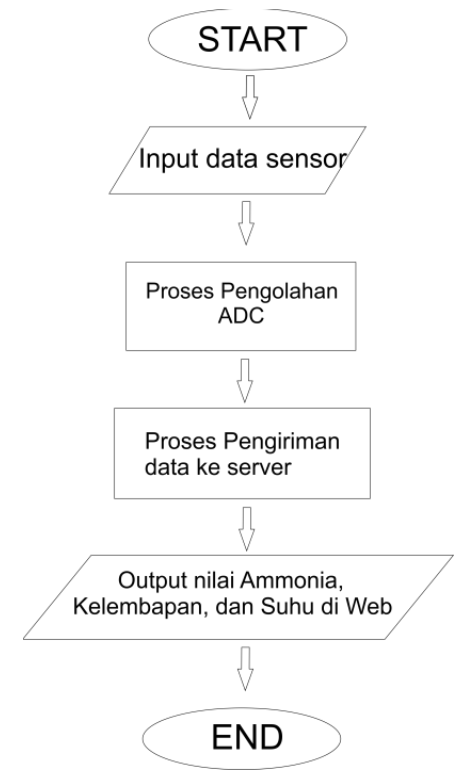

Gambar 5. Diagram alir konsep program

b. Perancangan Perangkat

Selain terdapat 2 benda yang utama, terdapat juga beberapa benda pelengkap, yakni resistor, motherboard, kabel jumper, kabel RJ45, dan Ethernet Shield. Perangkat ini akan menjadi 2 kelompok alat (lihat Gambar 4). Kelompok pertama berfungsi untuk mengambil data. Kelompok satunya untuk mengolah dan mengirimkan data.

c. Pembuatan Perangkat

Pembuatan alat ini memudahkan koordinator ataupun manager petugas kebersihan untuk mengontrol kelayakan yang ada. Penggunaannya juga cukup mudah, hanya menekan tombol pada alat tersebut, keadaan toilet akan terdokumentasi dan data akan langsung disimpan dalam server. Alur pembuatan perangkat tampak pada Gambar 5.

Cara kerja alat ini adalah sebagai berikut:

a) Sensor TGS2602 terhubung dengan arduino

b) Sensor TGS2602 mendeteksi amoniak

c) Nilai amoniak yang terdeteksi diubah ke digital melalui Analog Digital Converter yang sudah ada di arduino

d) Nilai amoniak yang terdeteksi dikirim ke server menggunakan Ethernet Shield

e) Server menampilkan Nilai Amonia yang telah diterima 
d. Pengujian Perangkat

a) Pengujian Sensor

Pengujian sensor dimaksudkan untuk melakukan proses kalibrasi atau konfirmasi terhadap fungsi sensor. Pengujian dilakukan dengan membuat satu set cairan dengan kadar yang telah ditentukan. Pembacaan pada sensor dicermati dan dipastikan setara seperti kadar cairan yang telah ditentukan.

b) Pengujian Software

Sensor yang sudah dirangkai, diuji untuk menentukan interval pengambilan data, durasi penilaian kualitas toilet, dan bagaimana cara menilainya. Nilai yang sudah didapat dari sensor akan dibandingkan dengan batas ambang kadar amoniak. Apabila nilai dari sensor lebih tinggi dibanding dengan batas ambang yang ada, maka petugas cleaning service akan mendapat mendapatkan notifikasi untuk membersihkan kamar mandi. Pemberitahuan berupa pesan singkat melalui SMS Gateway yang dikirimkan langsung dari server.

c) Pengujian Semua Perangkat

Prototipe dirangkai terlebih dahulu. Alat yang dirangkai terdiri dari 1 sensor, yakni sensor TGS2602, arduino, dan ethernet shield. Rangkaian sensor diletakkan pada suatu ruangan yang sudah didesain seperti keadaan udara yang ada di toilet. Sedangkan arduino yang berlaku sebagai pengolah data diletakkan jauh dari ruangan. Antara arduino dan sensor dihubungkan dengan kabel RJ45. Selain itu, pengujian dilakukan untuk mengetahui kekurangan pada alat dan sistem yang telah dibuat. Tahap ini dilakukan untuk mengetahui kekurangan apa saja yang yang terdapat pada alat dan sistem yang dibuat.

e. Analisis

Analisis dilakukan terhadap hasil pembacaan data kadar amoniak di beberapa toilet kampus UMS dengan menggunakan regresi linier sederhana. Kadar amoniak merupakan variabel X sedangkan bau toilet yang diukur dengan menggunakan skala likert menjadi variabel Y.

\section{Hasil dan Pembahasan}

\subsection{Kalibrasi perangkat MAS TUQUL}

Proses pengujian ketepatan pembacaan sensor dilakukan dengan melakukan kalibrasi. Menguji coba sensor tersebut dengan amonia yang telah ditentukan ukurannya. Pengukuran dilakukan melalui beberapa kali percobaan. Dan hasil dari pengukuran tersebut adalah sensor sudah bisa untuk membaca kadar amoniak sesuai dengan ukurannya. Hasil pembacaan sensor dapat dilihat pada grafik Gambar 6. Sumber vertikal menunjukkan nilai ppm dari cairan sedangkan sumbu horizontal menunjukkan waktu pembacaan. Setelah lebih dari satu menit, hasil pembacaan sensor sudah mendekati sama dengan nilai konsentrasi bahan yang diukur, yaitu sebesar $6 \mathrm{ppm}$.

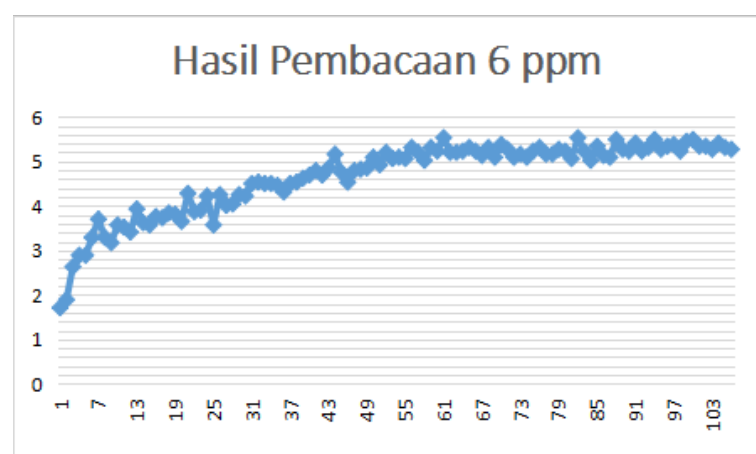

Gambar 6. Hasil pembacaan sensor

\subsection{Amoniak sebagai indikator}

Untuk mengetahui seberapa besar hubungan kadar amoniak terhadap bau toilet, dilakukan analisis regresi linier sederhana. Variabel Y menunjukkan tingkat bau pada skala likert dengan makna sebagai berikut: 1 . Wangi sekali, 2. Wangi, 3. Biasa, 4. Bau, 5. Bau sekali. Skala likert merupakan variabel ordinal yang ditunjukkan dengan Y. Variabel X merupakan kadar amoniak pada satuan ppm. Koefisien regresi linier diestimasi dengan metode least square. Metode itu mengharuskan analisis dilakukan menggunakan variabel interval. Oleh karena itu, variabel Y harus diubah menjadi skala interval, dengan menggunakan metode successive interval.

Telah dilakukan 16 pengamatan yang menghasilkan data seperti pada Tabel 1. Pada pengamatan, kadar amoniak ditambah secara perlahan (variabel X pada tabel). Kemudian persepsi responden diamati melalui pernyataan tingkat bau. Setelah diperoleh data, selanjutnya dilakukan analisis regresi linier yang hasilnya ditunjukkan pada Gambar 7.

Tabel 1. Nilai variabel X pada skala Likert

\begin{tabular}{cccc}
\hline $\begin{array}{c}\text { Nomor } \\
\text { pengamatan }\end{array}$ & $\begin{array}{c}\text { Variabel } \\
\mathbf{Y}\end{array}$ & $\begin{array}{c}\text { Transformasi } \\
\mathbf{X}\end{array}$ \\
\hline 1 & 2 & 1 & 0.05 \\
2 & 2 & 1 & 0.06 \\
3 & 2 & 1 & 0.06 \\
4 & 2 & 1 & 0.05 \\
5 & 3 & 2.271106291 & 0.1 \\
6 & 3 & 2.271106291 & 0.1 \\
7 & 3 & 2.271106291 & 0.08 \\
8 & 3 & 2.271106291 & 0.07 \\
9 & 3 & 2.271106291 & 0.08 \\
10 & 3 & 2.271106291 & 0.09 \\
11 & 3 & 2.271106291 & 0.08 \\
12 & 3 & 2.271106291 & 0.07 \\
13 & 4 & 3.542212581 & 2.7 \\
14 & 4 & 3.542212581 & 2.9 \\
15 & 4 & 3.542212581 & 3 \\
16 & 4 & 3.542212581 & 3.3 \\
\hline & & &
\end{tabular}




\begin{tabular}{|c|c|c|c|c|c|c|c|c|}
\hline \multicolumn{9}{|l|}{ SUMMARY OUTPUT } \\
\hline \multicolumn{9}{|c|}{ Regression Statistics } \\
\hline Multiple R & 0.81880309 & & & & & & & \\
\hline R Square & 0.67043849 & & & & & & & \\
\hline Adjusted R Square & 0.64689838 & & & & & & & \\
\hline Standard Error & 0.55160867 & & & & & & & \\
\hline Observations & 16 & & & & & & & \\
\hline \multicolumn{9}{|l|}{ ANOVA } \\
\hline & $d f$ & SS & MS & $F$ & gnificance & & & \\
\hline Regression & 1 & 8.66588 & 8.66588 & 28.48069 & 0.000105 & & & \\
\hline Residual & 14 & 4.25981 & 0.304272 & & & & & \\
\hline \multirow[t]{2}{*}{ Total } & 15 & 12.92569 & & & & & & \\
\hline & Coefficients & andard Erı & $t$ Stat & P-value & Lower 95\% & Upper 95\% & ower 95.0\% & Ipper 95.0 \\
\hline Intercept & 1.80451297 & 0.163282 & 11.05149 & $2.67 \mathrm{E}-08$ & 1.454307 & 2.154719 & 1.454307 & 2.154719 \\
\hline X Variable 1 & 0.58369766 & 0.109374 & 5.33673 & 0.000105 & 0.349115 & 0.818281 & 0.349115 & 0.818281 \\
\hline
\end{tabular}

Gambar 7. Hasil analisis regresi linier

Tabel 2. Prediksi tingkat bau berdasarkan kadar amoniak

\begin{tabular}{cccccc}
\hline $\mathbf{Y}$ & 1 & 2 & 3 & 4 & 5 \\
\hline $\mathbf{X}$ & 0 & 0.33 & 2.04 & 3.76 & 5.47 \\
\hline$(\mathrm{ppm})$ & & & & & \\
\hline
\end{tabular}

Hasil analisis regresi menunjukkan hubungan antara tingkat bau menurut persepsi manusia dan kadar amoniak, yaitu $\mathrm{Y}=1.8045+0.5836 \mathrm{X}$ dengan koefisien determinasi 67\%. Kadar amoniak mempengaruhi 67\% dari bau toilet. Sedangkan 33\% bau disumbangkan dari bahan selain amoniak.

\subsection{Pembahasan}

Setelah diperoleh persamaan regresi, dapat dilakukan prediksi kadar amoniak untuk setiap kategori bau toilet sebagaimana disajikan di Tabel 2. Entri tabel 2 diperoleh dengan memasukkan nilai variabel $Y$ dan menghitung nilai variabel $\mathrm{X}$ yang setara.

Dengan adanya korelasi antara kadar amoniak dan persepsi bau oleh manusia, dapat diprediksi tingkat kenyamanan toilet berdasarkan kadar amoniak yang terukur. Jika diinginkan bahwa toilet tidak boleh dipersepsikan sebagai "bau" dan "bau sekali", maka ambang batas kadar amoniak yang terukur tidak boleh lebih dari 3,76 ppm, sesuai nilai pada Tabel 2. Jika kadar amoniak melebihi batas tersebut, maka toilet harus segera dibersihkan.

Perangkat Mas Tuqul masih dalam proses pengembangan, yaitu untuk memanfaatkannya dalam manajemen kebersihan toilet di suatu kawasan atau gedung. Kemampuan perangkat Mas Tuqul memprediksi bau toilet dengan mengikuti persepsi manusia menjadi penting. Jika sensor ini diletakkan di berbagai toilet pada sebuah gedung, maka pengawas kebersihan gedung dapat melakukan pemantauan terhadap kebersihan toilet. Jika ada toilet yang melebihi ambang batas, maka perangkat Mas Tuqul akan memberikan notifikasi kepada petugas yang akan segera membersihkan toilet. Pengawas kebersihan dan bahkan manajer gedung juga dapat melihat rekaman data dalam sehari atau seminggu atau dalam rentang waktu tertentu dan mencari tahu apakah toilet pernah terbengkalai dalam arti bau melebihi ambang batas dalam waktu lama.
Standar kementerian kesehatan menunjukkan bahwa ambang batas toilet yang sehat adalah kadar amoniak tidak boleh melebihi 2 ppm [6]. Angka kadar amoniak ini termasuk kategori "normal" menurut hasil penelitian penulis. Setidaknya menurut persepsi responden penelitian ini, kadar amoniak sedikit melebihi batas menurut kementerian kesehatan, masih dikategorikan normal oleh responden.

\section{Kesimpulan}

Berdasarkan penelitian yang dilakukan, dapat disimpulkan bahwa perangkat Mas Tuqul dapat digunakan untuk mendeteksi bau toilet. Bahan yang dijadikan tolok ukur adalah kadar amoniak yang terkandung dalam udara di toilet. Hasil pengukuran kadar amoniak dapat dikonversi menjadi persepsi tingkat bau. Perangkat Mas Tuqul ini bisa digunakan untuk mengelola kebersihan toilet di suatu kawasan atau gedung.

\section{Ucapan Terima Kasih}

Terima kasih disampaikan kepada Direktorat Jenderal Pembelajaran dan Kemahasiswa (Belmawa), Kemenristekdikti yang telah memberikan pendanaan sehingga kegiatan penelitian ini bisa berjalan.

\section{Referensi}

[1] Chaunie Brusie. (2017, Pebruari) Health Line. [Online]. http://www.healthline.com/health/howoften-should-you-pee

[2] Eggert Moeller, J. F. McIntosh, and D. D. Van Slyke, "Studies of Urea Excretion. II: Relationship Between Urine Volume and the Rate of Urea Excretion by Normal Adults," Journal of Clinical Investigation, vol. 6, no. 3, p. 427, 1928.

[3] Leann Mikesh. (2015, April) Live Strong. [Online]. http://www.livestrong.com/article/516316-what-isnormal-urinary-output-for-an-adult/

[4] Yuyun L Rofiqoh and Eddy S Soedjono, "Studi Potensi Urin Manusia Hasil Composting Toilet dalam Sistem Ecological Sanitation (ECOSAN) (Studi Kasus Pusdakota Surabaya)," Institut Teknologi Sepuluh Nopember, Surabaya, Skripsi 2010. 
[5] Departemen Pekerjaan Umum. (2011) Peraturan Menteri Pekerjaan Umum tentang Pedoman Pemeliharaan dan Perawatan Bangunan Gedung. [Online]. http://www.pu.go.id/uploads/ services/2011-12-01-12-59-56.pdf

[6] Kementerian Kesehatan Republik Indonesia. (2014) Peraturan Menteri Kesehatan Republik Indonesia Nomor 8 Tahun 2014 tentang Pelayanan Kesehatan SPA. [Online]. http://www.peraturan.go.id/ permen/kemenkes-nomor-8-tahun-2014.html

[7] Hendi Setiawan. (2015, Juni) Kompasiana. [Online]. http://www.kompasiana.com/ hendisetiawan/kenapa-toilet-umum-kebanyakankotor_551ad19ca333115820b659a7
[8] Klaus Schawb, "The Global Competitiveness Report 2014-2015,” World Economic Forum, 2014.

[9] Badan Pusat Statistik. (2016) Badan Pusat Statistik. [Online]. https://www.bps.go.id/linkTabelStatis/ view/id/1537

[10] Sri Noviarni. (2014, Oktober) Koran Sindo. [Online]. http://lifestyle.sindonews.com/read/930083/152/ toilet-kotor-sumber-penyakit-1417143870/10

[11] Anto Dajan, "Pengantar Metode Statistik Jilid II", Lembaga Penelitian, Pendidikan, dan Penerangan Ekonomi dan Sosial, 1973. 